\title{
TEACHING BASED ON CHALLENGES FOR THE SUBJECT STEEL STRUCTURES
}

\author{
J. Segura Alcaraz, E. Juliá Sanchis, I. Montava Belda, J.M. Gadea Borrell \\ Universitat Politècnica de València (SPAIN)
}

\begin{abstract}
The evolution of information and communication technologies has changed the way in which agents involved in teaching have access to information. The classic concept of transmission of knowledge, valid 30 years ago, of a lecture (message) in a physical classroom (space) at a certain time (time) has now become obsolete. There are many disciplines taught in universities that can adapt their teaching model to hybrid face-to-face and online systems, where class time is used in the application and discovery of knowledge by the student. In this paper, a learning methodology based on challenges is proposed for the subject of Steel Structures of the Degree in Mechanical Engineering of the Universitat Politècnica de València. The organization of the contents and didactic tools used: tele-training platforms, flipped teaching, commercial software for steel structures ..., allows the teaching of the subject to be carried out face-to-face or online without changes and brings the student closer to the professional reality of steel structures. The results obtained during the last 5 years show a high percentage of passes and a high degree of student satisfaction based on surveys.
\end{abstract}

Keywords: steel structures, challenges, active learning.

\section{INTRODUCTION}

Challenge-based learning is the opposite of "classical" learning based on course topics. Learning based on a succession of course topics, the teacher transmits his knowledge to the student, in a model that could be called transmissive-reproductive, where the student reproduces the teacher's vision of the knowledge transmitted and thus acquires the specific competences of the subject. On the other hand, in the challenge-based learning model, the subject is not based on a succession of course topics, the central focus of the subject is a succession of challenges, generally with a progression of increasing difficulty. The teacher must create a learning environment, providing the student with tools, where the challenges are developed. The students become the protagonists of their own learning through experience and in this way acquire specific competences. Challenge-based learning is based on four fundamental factors: competence acquisition, understanding, student engagement and self-regulation.

Teaching based on a chronological succession of course topics is based on the erroneous principle that the student acquires competence with knowledge, the more knowledge the more competence. However, competence is acquired when acting with autonomy and responsibility in a series of challenges of increasing complexity [1][2][3][4]. Comprehension is acquired through reasoning, the student, by reasoning through the challenges in a guided way, manages to understand the knowledge [5] [6] and accumulates the experience to act by analogy in future situations [7]. To encourage student engagement, the level of the challenge must represent an advance with respect to the initial state and at the same time be accessible to the student, so that on achieving it the students feels the satisfaction of having reached the goal or having achieved the objective [8] [9]. Finally, within a more flexible spacetime, students set the pace of their learning by self-regulating, interacting with the rest of their partners and comparing the different solutions to the challenge.

In this work, a learning methodology based on challenges is proposed for the subject of Steel Structures of the Degree in Mechanical Engineering of the Universitat Politècnica de València. The methodology in the subject has been implemented and improved during the last 5 years until reaching the current contents and programming, going from a passive methodology to an active one. The results of the student satisfaction surveys and the number of passes in the subject show the goodness of the implemented methodology. 


\section{METHODOLOGY}

\subsection{Subject and Challenges}

The subject on which the teaching methodology based on challenges has been implemented, is Estructuras Industriales 1 in 4th course of the Mechanical Engineering Degree at the Universitat Politècnica de València. The subject is an introductory course in the design of steel structures for industrial facilities, the objective is to develop students with an understanding of the behavior and design of steel members and systems. Upon completion of this course, students should be able to apply relevant CTE and EAE Spanish standards provisions to ensure safety and serviceability of structural steel elements and utilize advanced computer software packages (Artek Tricalc and Cype Metal 3D) for the analysis and design of steel structures. Students are familiar with strength of materials and structural analysis from previous courses.

Three challenges are proposed to the students in increasing order of difficulty:

Challenge one, deep built-up beam: this is an introductory challenge to deal with basic topics like loads, loads combinations, cross section classification, ultimate limit states of resistance in cross sections, ultimate limit states of resistance in members, ultimate limit state of buckling, ultimate limit state of lateral bucking, ultimate limit state of web buckling, ultimate limit state of shear buckling of the web, serviceability limit states..etc. Based on common initial data, each student must give a solution to the challenge with the objective of optimizing the beam cross section.

Challenge two, single story portal frame car parking: in the second challenge the students, work with new concepts like the assessment of frame stability or the significance of the second order effects, the allowance of second order effects, the inclusion of allowances for imperfections in the analysis. Based on common initial data, each student must give a solution to the challenge with the objective of minimizing the weight and cost of the structure. Fig 1 shows a CYPE 3D model of a simple single story portal frame car parking.
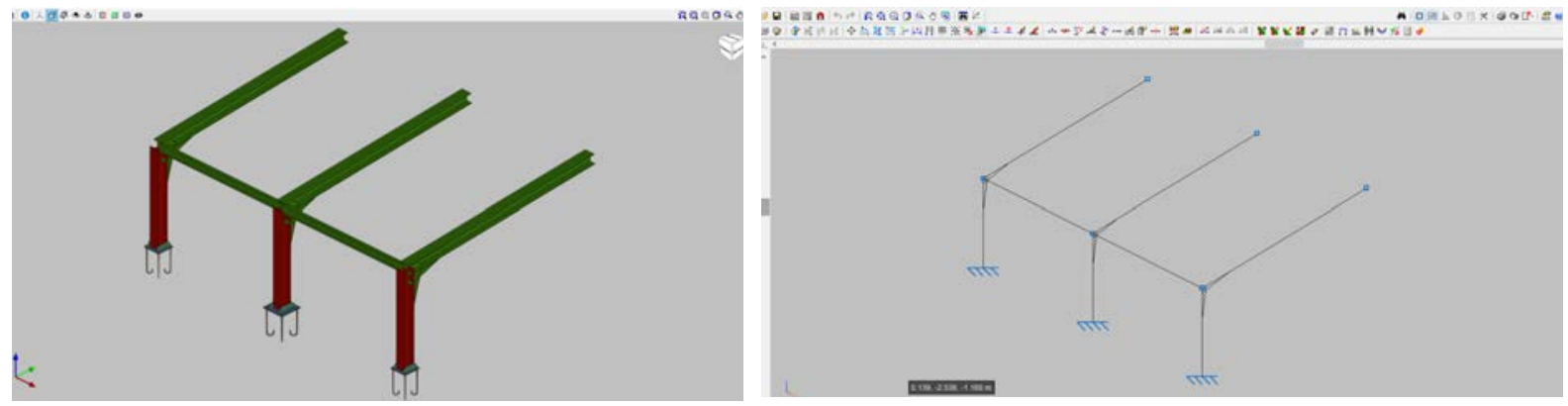

Figure 1. CYPE 3D model of a car parking structure.

Challenge three, industrial building: the third and last challenge is the calculation and design of an industrial building. Based on common initial data, each student must give a solution to the challenge with the objective of minimizing the weight and cost of the structure. Fig 2 shows a Artek Tricalc model of an industrial building.

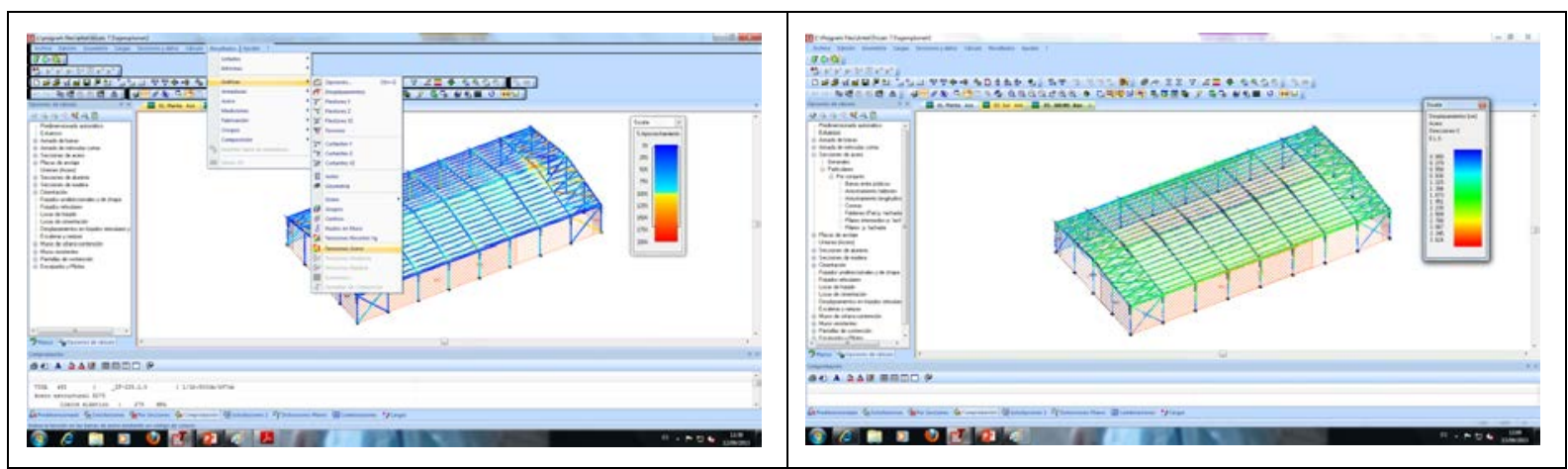

Figure 2. Artek Tricalc model of an industrial steel structure. 


\subsection{Course Schedule and resources}

The subject Estructuras Industriales 1 has 6 credits and is programmed in 30 class sessions of 2 hours, during 15 weeks with 4 hours per week. The classes are face-to-face but for the last year the sessions have been transmitted synchronously via Microsoft Teams, in this way students can follow the course remotely. In addition, the classes are recorded, and students can consult them in Microsoft Stream. All the material, resources and software packages necessary to manage each challenge are in the teletraining platforms Poliformat (subject place) and Polilabs (software) of the Universitat Politècnica de València.

For each challenge there is a common time distribution with three parts. Part 1 explanation of the challenge, the teacher explains the challenge, shows the material and tools necessary for the challenge and shows some worked examples, Part 2 time for students to work on the challenge autonomously and Part 3 presentation report of the results of the challenge in front of the rest of their peers. Table 1 shows the time distribution of the subject.

Table 1. Hours distribution per challenge.

\begin{tabular}{l|c|c|c|c}
\hline \hline & $\begin{array}{c}\text { Presentation of the } \\
\text { subject (hours) }\end{array}$ & $\begin{array}{c}\text { Challenge 1 } \\
\text { (hours) }\end{array}$ & $\begin{array}{c}\text { Challenge 2 } \\
\text { (hours) }\end{array}$ & $\begin{array}{c}\text { Challenge 3 } \\
\text { (hours) }\end{array}$ \\
\hline Part1, Explanation & 2 & 2 & 2 & 4 \\
\hline Part2, Students Work & & 12 & 8 & 22 \\
\hline Part3, Presentation & 2 & 2 & 2 & 2 \\
\hline Weeks & 1 & 4 & 3 & 7 \\
\hline \hline
\end{tabular}

\subsection{Assessment}

The evaluation system takes into account different aspects and is organized in 3 categories. Category 1: components of the report appearance and organization; Category 2: Calculations and results; Category 3: conclusions. Table 2 shows the categories and the rating levels for each category considered for the assessment.

Table 2. Assessment system.

\begin{tabular}{|c|c|c|c|c|c|}
\hline Category & 4 & 3 & 2 & 1 & Weight \\
\hline $\begin{array}{l}\text { Components of } \\
\text { the report } \\
\text { appearance and } \\
\text { organization: } \\
\text { data, tables, } \\
\text { graphs... }\end{array}$ & $\begin{array}{l}\text { All required elements } \\
\text { are presented. The } \\
\text { contents are well } \\
\text { organized and } \\
\text { presents a professional } \\
\text { appearance }\end{array}$ & $\begin{array}{c}\text { All required } \\
\text { elements are } \\
\text { presented. The } \\
\text { contents are well } \\
\text { organized }\end{array}$ & $\begin{array}{c}\text { Few requirements } \\
\text { are missing. The } \\
\text { format of the } \\
\text { report does not } \\
\text { help to organize } \\
\text { the material and } \\
\text { to understand the } \\
\text { contents } \\
\end{array}$ & $\begin{array}{l}\text { Several required } \\
\text { elements are } \\
\text { missing. The } \\
\text { contents are not } \\
\text { well organized }\end{array}$ & $10 \%$ \\
\hline $\begin{array}{l}\text { Calculations and } \\
\text { results }\end{array}$ & $\begin{array}{l}\text { All the calculations are } \\
\text { shown, and the results } \\
\text { are correct. Results } \\
\text { are discussed }\end{array}$ & $\begin{array}{c}\text { Some calculations } \\
\text { are shown, and the } \\
\text { results are correct. } \\
\text { Results are } \\
\text { discussed although } \\
\text { unclearly }\end{array}$ & $\begin{array}{c}\text { Few calculations } \\
\text { are shown, and } \\
\text { the results are } \\
\text { not correct }\end{array}$ & $\begin{array}{c}\text { No calculations } \\
\text { and results are } \\
\text { shown }\end{array}$ & $60 \%$ \\
\hline Conclusions & $\begin{array}{c}\text { Conclusion includes } \\
\text { whether the findings } \\
\text { supported the initial } \\
\text { data, its relation to the } \\
\text { objectives, possible } \\
\text { sources, or } \\
\text { improvement and what } \\
\text { was learned from the } \\
\text { challenge } \\
\end{array}$ & $\begin{array}{c}\text { Conclusion } \\
\text { includes whether } \\
\text { the findings } \\
\text { supported the initial } \\
\text { data and what was } \\
\text { learned from the } \\
\text { challenge }\end{array}$ & $\begin{array}{c}\text { Conclusion } \\
\text { includes what } \\
\text { was learned from } \\
\text { the challenge }\end{array}$ & $\begin{array}{l}\text { No conclusion } \\
\text { was included }\end{array}$ & $30 \%$ \\
\hline Rating level & 10 & 7.5 & 4.5 & 1 & \\
\hline
\end{tabular}




\section{RESULTS}

Over the last 5 years, it is observed that challenge-based learning offers multiple benefits, the methodology approach students with work-life environments, increases the participation in class, allow students to discuss and construct concepts relationships in situations that involve real-life problems and projects. Regarding student engagement, the student motivation and self-efficacy is improved. The student satisfaction surveys of the last 5 years show a growing acceptance of the methodology, with scores above 6 in all years. On the other hand, the number of passes since the implementation of the methodology has been $100 \%$. Fig. 3 shows the satisfaction of students with teaching over the last 5 years.

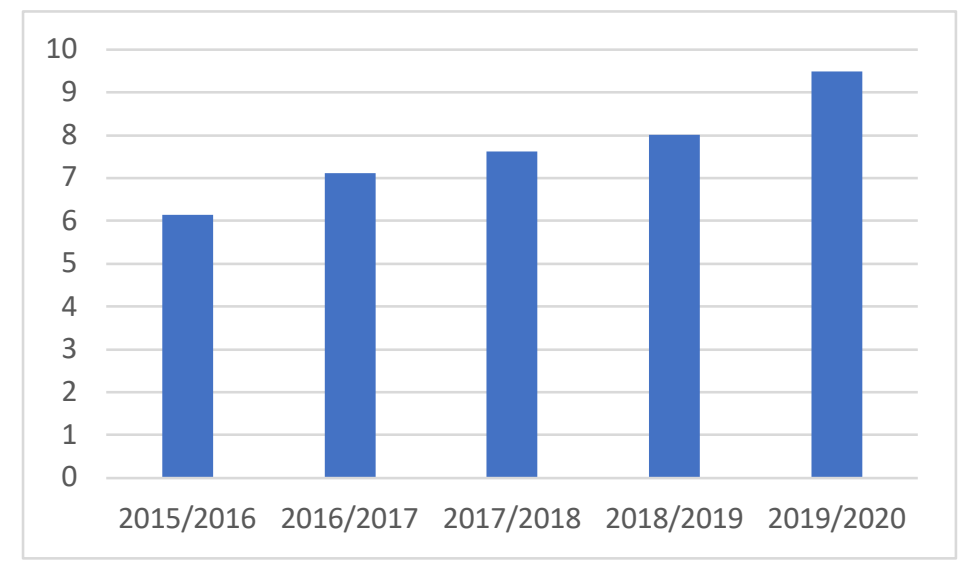

Figure 3. Results of student's surveys.

\section{CONCLUSIONS}

This methodology has been implemented and improved during the last 5 years. It started with a hybrid model where theory classes were combined with small challenges. In the final assessment, classical exam-based techniques were still used, and the exam rantings had a higher weight in the final assessment than the challenges. Progressively using the results of student surveys, the teaching model changed from passive to active and in the last 5 years the teaching is based completely on challenges. The objective of motivating students and bringing the teaching of the subject closer to real-life situations has been achieved.

\section{REFERENCES}

[1] R. E. Haskell, Transfer of Learning: Cognition and Instruction. Academic Press, 2011.

[2] L. Andrews, "Transfer of Learning: A Century Later," Journal of Thought, Vol. 37, No. 2, pp. 63-72, 2002.

[3] A. Collins, J.S. Brown, S.E. Newman, " Cognitive apprenticeship.Thinking," Journal of Philosophy for Children, Vol. 8, No. 1, pp. 2-10, 1988.

[4] P. T. Knight, M. Yorke, "Employability and Good Learning in Higher Education," Teaching in Higher Education, Vol. 8, No. 1, 2003.

[5] A. Blackwell et alt, "Transforming work experience in higher education," British Educational Research Journal, Vol. 26, pp. 269-286. 2001.

[6] M. Eraut, Developing Professional Knowledge and Competence, London: Falmer Press,1994.

[7] L. Alfieri, T. J. Nokes-Malach, C. D. Schunn, "Learning through case comparisons: A meta-analytic review," Educational Psychologist, Vol. 48, No. 2, pp. 87-113, 2013.

[8] T. C. URDAN, The Role of Context: advances in achievement and motivation, pp. Stamford: JAI Press Inc, 1999.

[9] E. Seymour, A. B. Hunter, "Establishing the benefits of research experiences for undergraduates in the sciences: First Findings from a three-year Study" Science Education, Vol. 88, No. 4, pp. 493 534, 2004. 